\title{
The Academic Achievement of Elite Athletes at an Australian University: Debunking the Dumb Jock Syndrome
}

\author{
Steve Georgakis ${ }^{1}$, Rachel Wilson ${ }^{1} \&$ Jamaya Ferguson $^{1}$ \\ ${ }^{1}$ The University of Sydney, Australia \\ Correspondence: Steve Georgakis, The University of Sydney, Australia. E-mail: steve.georgakis@sydney.edu.au
}

Received: January 21, 2014

Accepted: February 28, 2014

Online Published: May 4, 2014

doi:10.5430/ijhe.v3n2p120

URL: http://dx.doi.org/10.5430/ijhe.v3n2p120

\begin{abstract}
Elite athletes and their academic achievement in higher education have long been subject to considerable debate within North American scholarship. This interest proliferated especially after the release of the Knight Report (2001), which, amongst other findings, revealed a clear negative link between elite athletes and their academic achievement. While sport has always had a long and prominent presence in Australian higher education, both sport and education scholars have given very little attention to this area. To rectify this neglect, this study investigates the academic achievement of elite athletes $(\mathrm{N}=313)$ at an Australian university and compares their results to the general student population in the 2012 academic year. Using both qualitative interviews $(n=20)$ and quantitative secondary data analysis, the findings suggest that despite heavy sporting commitments and necessarily demanding training timetables, the sampled elite athletes performed at levels equal to, or superior to, their peers. In particular they show a lower failure rate. These findings are discussed in relation to student abilities, education program management and the challenges faced in terms of elite athlete stereotyping.
\end{abstract}

Keywords: Higher education, Sport, Academic achievement, Attainment, Elite athletes, Australia

\section{Introduction}

There has been considerable interest in the field of academic achievement of elite athletes within North American literature due to the fact that, despite their relatively small numerical representation, elite athletes occupy a socially prominent position (Simons, Bosworth, Fujita \& Jensen, 2007). The literature in this field is dominated by scholars from the United States, where elite athletes have been placed under a concentrated microscope of academic and sporting analysis for many years; and where sustained research and documentation accelerated after the publication of the far-reaching Knight Report (2001) which painted a very negative picture of elite athletes. Corresponding to this report and subsequent literature, were the growing public stereotypes of elite athletes that were perpetuated and labeled as 'dumb jocks', especially by the mass media, which reported specific high-profile examples (Sack, 2001; Suggs, 2003a; 2003b).

While the broader relationship between sport and educational attainment has also been subject to significant analysis in North American literature, very little interest has been generated in the Australian scene. This lack of literature is surprising for a number of reasons. Firstly, because much of Australian sport and education has been extensively documented. Secondly, since the establishment of Australian schools, colleges and universities, sport has played a central role in the student experience and to this very day, most educational institutions support and invest in sport. Finally, and perhaps most pertinently, the neglect has been more obvious since the introduction of national high stakes literacy and numeracy testing where considerable scrutiny has been placed on not only all the key-learning areas that make up the proposed school curriculum, but also on other areas such as sport. Consequently, all curriculum areas have been keen to demonstrate their link to academic performance in a bid to justify their position in the Australian educational landscape (Lingard, 2011).

In order to make a contribution toward rectifying this neglect in Australian literature, the academic achievement of a cohort of elite athletes at an Australian university was compared to the general university population. Students who formed a part of the University's elite athlete program (EAP) had all their grades from the 2012 academic year examined to answer the following research question: 1) How does the University achievement of elite athletes compare to the attainment of the general student University population? and 2) How does the relative achievement of university athletes vary by their gender, sport and whether they choose residential college accommodation? 


\section{Background Information}

For over three decades, the literature surrounding elite athletes' academic achievement has overwhelmingly reported that they are low attainers relative to their peers (Hildenbrand, 2005; Intrator \& Seigal, 2008; Lewis, 1997; Miller \& Kerr, 2002; Mixon, 1995; Pascarella \& Smart 1991; Rasmussen, 2009; Ryan, 1989; Shulman \& Bowen, 2001; Stegman, 2000). While it is beyond the scope of this paper to consider the extensive literature in this field in detail, it is important to outline some of the key and clear themes which emerge from the research. The first theme to emerge is the overwhelming adoption of quantitative research data collection; where end of year academic results, graduation rates and full grade point averages (GPA) are compared between elite athletes and the general university population (Comeaux \& Harrison, 2011; Espenshade, Chung \& Walling, 2004; Hildenbrand, 2005; Shulman \& Bowen, 2001; Rasmussen, 2009). When gender and ethnicity are controlled for, the correlation becomes even more pronounced (Hildenbrand, 2005). Further, the negative correlations predominant in these studies are more prominent when heavily commercialized sports (American Football and Basketball) are examined. As Rasmussen (2009) reported: "the graduation rates for elite student athletes, especially those in high profile, revenue generating sports, such as football, still remain low" (p.3).

Regardless of gender, minority group, or the profile or commercialization the sport, North American elite athletes underperform and underachieve, when compared to their non-athletic peers. This verdict in the literature and the negative attention in the mass media has constituted and further reinforced the culturally accepted stereotype of elite athletes as 'dumb jocks' (Hildenbrand, 2005; Hollis, 1998; King, 1998; Lambertson, 1998; Lewis, 1997; Mixon, 1995; Pascarella \& Smart 1991; Richards \& Aires, 1999; Ryan, 1989; Shulman, \& Bowen, 2001; Stuart, 1985; Unruh, 2001).

Whilst there are innumerable studies which identify this negative link, some studies have begun to investigate the reasons for this phenomenon (Hildenbrand, 2005; Hollis, 1998; King, 1998; Lewis, 1997; Mixon, 1995; Pascarella \& Smart, 1991; Richards \& Aries, 1999; Ryan, 1989; Shulman \& Bowen 2001; Stuart, 1985; Unruh, 2001). Although a number of reasons are reported, one of the most dominant reasons is linked to low expectations. Hildebrand (2005) noted that "athletes are rarely expected to be stellar in the classroom, as long as they display their skills on the playing field" (p.54), and therefore this results in athletes not reaching the academic benchmark of the class (Hildebrand, 2005; Shulman \& Bowen, 2001). Another reason relates to low entry mark; Rasmussen (2009) highlights that due to lower entry standards, many of these athletes find themselves in classes filled with academically better prepared peers, and thus the athletes cannot compete with their limited prior learning status. Finally, there is also research linking this negative correlation to a lack of support services. Lambertson (1998) linked poor performance to a lack of student support services provided and concluded that the universities that did not enforce mandatory study groups, had the poorest results, lowest graduation rates and lowest GPAs for elite athletes; indicating that study sessions proved a major variable in an elite athlete's academic milieu.

There are however some of studies that have challenged this negative correlation and it would be remiss not to include them (Jonker, et al., 2009; Richards \& Aries, 1999; Wolnaiak, Pierson, \& Pascarella, 2001; Umbach, Palmer, Kuh, \& Hannah, 2006). Jonker, et.al. dispute the 'dumb-jock' stereotype for female athletes at least, because unlike male athletes, they are not only highly engaged, but also perform better in their academics. These results are congruent with Dexter (1999), Durand-Bush and Salmela (2002) and Schroeder (2000), who all reported on sub-groups that had performed well within their respective settings. These studies suggest that recognition of sub-groups within elite athletes is important to understanding their levels of attainment.

While not directly linked to elite athletes, there is now an emerging body of literature, which suggests that participation in sport may in fact contribute to better academic outcomes (Berg, 2010, Jonker, et al., 2009; Durand-Bush \& Salmela's, 2002). For example, there is no doubt that the healthier an individual is, the more productive they are (Janssen \& LeBlanc, 2010). Recent developments in neuroscience also suggest that physical activity also greatly enhances and further develops cognitive functioning (Martin, 2010; Berg, 2010). We can assume that elite athletes have high levels of physical activity and there may also be other benefits related to better time management because of busy schedules; athletes are experienced in meeting deadlines and being organized. Durand-Bush and Salmela (2002) reported on elite athletes' "ability to manage tight schedules and their capacity to utilize their free time in a more economical way" (p.165). Some studies have demonstrated that elite athletes are able to transfer the skills, traits and characteristics developed through sporting experiences, to achieve in their academic environment. Jonker, et al. (2009) and Durand-Bush and Salmela's (2002) studies both reveal that elite athletes 'goal-oriented and problem-focused' characteristics are transferred into their academic domains to enhance their educational outcomes. They identified time management skills, goal-setting techniques, coping strategies, ability to 
focus and being highly motivated and committed to achieve, as personal attributes that are used to enhance academic ambitions (Durand-Bush \& Salmela 2002; Jonker, et al., 2009). The studies clearly reveal that the elite athlete's approach to their sport integrates within their educational domain to facilitate their academic outcomes.

Within the Australian university context most of the literature which considers elite athletes derives from historical perspectives highlighting the significant role played by elite athletes in the growth and consolidation of Australian sport (Sherington \& Georgakis, 2008; Selleck, 2004). At the University of Sydney, there are discussions on all aspects of elite athletes including women (Lilienthal, 1997); clubs (Hickie, 1998) and individual athletes (FitzSimons, 1994). Even the general histories of the University of Sydney are keen to highlight the merits of its elite athletes (Horne \& Sherington, 2012). While sporting accomplishments are pivotal, research into athletes' academic performance is none existent.

Finally, the lack of Australian literature related to academic achievement and elite athletes raises an important question. While sport is a central feature in the Australian education setting and so prominent in Australian society, why is there also such an insignificant body of literature addressing academic achievement and sport more generally? Unable to answer his perplexing question, we make a small contribution to rectifying that gap and more specifically present the first analysis of the academic attainment of Australian elite university athletes.

\section{Methodology}

This mixed methods study combines a secondary data analysis of university attainment data with an interview survey of students. This is an explanatory, sequential mixed methods design; where quantitative analyses are followed by qualitative research to provide a more in-depth explanation of the phenomena involved (Creswell \& Clark, 2007).

In order to compare the academic results of EAP athletes and the general University population for the 2102 academic year, both descriptive and inferential statistical analyses were undertaken. This was followed by qualitative, semi-structured interviews with EAP students. In order to access both EAP athletes and general University student results, permission was granted by the University's Human Ethics Office.

\subsection{Participants}

The sample comprised of all athletes enrolled in the Elite Athlete Program (EAP) at a University in the city of Sydney, Australia in 2012. The EAP was formally founded in 1990, although the University has a long tradition of supporting elite athletes (Sherrington \& Georgakis, 2008). The program provides students with: an additional five entry marks for application to degree programs; additional support through tutoring; access to elite sporting facilities and services (specialist doctors and coaches); and also an EAP academic policy attendance that helps students negotiate their sporting commitments and academic requirements.

The sample consisted of the 313 undergraduate student athletes enrolled in the EAP program in 2012. These athletes were enrolled in degrees from fourteen faculties: Business, Health Sciences, Science, Pharmacy, Veterinary Science, Nursing, Arts, Medicine, Law, Engineering, Education, Dentistry, Architecture and Agriculture. Postgraduate EAP students were excluded from the study. The sample comprised both male (62\%) and female (38\%) athletes. The sports with the highest number of scholarship holders were Rugby Union, Athletics, Soccer, Rowing, Cricket, AFL and Hockey; each of these had more than 20 students. While students were spread across all the faculties of the University, the faculties with the highest number of students included Business, Health Science and Science. Residential college students comprised almost $20 \%$ of the total EAP undergraduate cohort.

\subsection{Procedures}

\subsubsection{Secondary data analysis}

In order to access both EAP athletes and general University student results, permission was granted by the University's Human Ethics Office. Individual, annonymised data was accessed for EAP students and aggregate summary data for the total student population was accessed for the units of study that EAP students had completed.

Student attainment was compared using Unit of Study, or individual course grades. Comparison at the unit of study level was necessary because assessment practices vary from course to course and different distributions in attainment were seen in different units of study.

In 2012, the 313 EAP athletes attempted 1,932 units of study. In the first semester, 991 units were attempted and in the second semester, 941. The number of units for each student varied, with some students completing one unit while others completed the maximum number ( 8 units). Those students with lower numbers of units did so because of part-time study or due to heavy sporting commitments. For example most of the University's 2012 Olympians did not enroll in any units in semester 2, due to Olympic Games commitments; nevertheless these students have been 
able to be included in the analysis because comparison is at the single unit of study level. In total, the average number of units attempted by each student in the 2012 academic year was approximately 6 . Whilst we acknowledge this load is different to other students (where average is 8) we maintain a simple comparison between students at unit of study level because the shift in load is part of the EAP accommodations and our overall intent is to examine university performance within the EAP context.

\subsubsection{Interviews}

To gain further understanding of the issues surrounding student achievement, semi-structured interviews were conducted with 20 EAP students. Hutchinson, Wilson \& Wilson (1994) highlight that "interviews are a fundamental data collection method used in qualitative research to help understand people's responses to a particular situation" (p.161). In this case, they were used to ask the student athletes about their academic experiences at university. Questions included: 1)What are the major barriers/hurdles to your academic performance at the University?; 2) What are the factors, which have helped your academic performance?; 3) Do you believe that playing sport has assisted your academic performance?; 4) What do believe is the perception of elite athletes by academic staff?; 5) What do believe is the perception of elite athletes by fellow students?; 6)What can the elite athlete program do to assist elite athletes studying at the university?; and 7) Is there anything else you would like to mention related to the link between sport and academic achievement?

A recruitment flyer was distributed via email to all EAP athletes. From the 33 athletes who agreed to take part in the interviews, 20 were randomly selected. The interviews took approximately 20 minutes and were conducted in a vacant office on campus.

\subsection{Analysis}

\subsubsection{Attainment data}

The secondary data analysis was a comparative analysis of EAP athletes' attainment, with summary attainment statistics for the general University population. To do this effectively, units of study completed by substantial numbers of EAP students were compared to the summary mean, quartiles and proportions in grades for the total cohort in those units.

In 2012, 63 units of study were completed by eight or more EAP athletes, but only six units with 13 or more students. All 63 units were analyzed for the proportions in grades. The six largest units were subject to inferential analysis to compare mean scores. Analysis of this data enabled an understanding of EAP athletes' academic progress relative to their peers. Analysis occurred at three levels: examining scores (t-test comparing mean scores); comparing proportions in grades; and comparing failure rates in units.

\subsubsection{Interview data}

Interviews were recorded and transcribed. Thematic analysis was used for "identifying, analyzing and reporting patterns (themes) within data" (Braun \& Clarke, 2006, p.79). For the purposes of transparency, the emerging themes are presented in a table with verbatim quotes from the interview data (See Table 2).

\section{Results}

Secondary data analysis comparing the EAP students to the full university cohort is presented first. This is followed by an analysis of performance trends within the EAP cohort by examining performance by gender, sport, faculty and residential college. These analyses are then informed by the findings of the interviews.

\subsection{Comparison between EAP and total student cohort}

Approximately one third of the EAP academic results (637) occurred within 63 units of study; all these units had eight or more EAP students enrolled in them. These units were the focus of the first analysis as it was impractical to compare performance in units with small EAP enrollments.

Within the 637 student results in these 63 units $58 \%$ of the EAP students received grades above the median. Overall, $21 \%$ of the EAP students were in the first quartile; while $37 \%$ were in the second quartile. The gender breakdown resulted in $61 \%$ of the EAP females above the median with $55 \%$ of the EAP males above the median. Thus we can conclude that in approximately one third of the units studied by EAP students, EAP students were overrepresented in the top two quartiles of student performance and female' performance is slightly stronger than males'. Inferential analyses were conducted for the six units with the largest EAP enrollments (these had 14 to 18 EAP enrollments). In these units differences between the mean scores of EAP and the total student cohorts were examined using a 
one-sample t-test. A comparison of mean scores and grades for the EAP students and the total student cohort are seen in Table 1.

EAP students' mean scores were significantly higher in Psychology 1001 $(\mathrm{t}=3.2, \mathrm{n}=17, \mathrm{p}<.05)$, Business Environment $(\mathrm{t}=4.3, \mathrm{n}=16, \mathrm{p}<.05)$; Accounting Business \& Society $(\mathrm{t}=2.9, \mathrm{n}=11, \mathrm{p}<.05)$. There was no significant difference found in Psychology 1002, Biomechanics of Human Movement and Mathematical Modeling. Thus, EAP students were observed to have equivalent average scores in three of these units and significantly higher average scores in the remaining three units. Mean EAP performance varied with gender but no clear trend is evident.

Examination of proportions in grades shows that EAP failure rates are equivalent or lower to overall failure rates in four out of the six courses. There are also higher proportions of students getting pass and credit grades in four out of six of the units. Although EAP students receive lower proportions of Distinction grades in four out of six of the courses, this trend is reversed when rare and elite High Distinction grades are considered and higher proportions are awarded to EAP students in the only three units in which these High Distinction grades were awarded.

Table 1. Comparison of mean scores and grades in six units with the highest EAP enrollments

\begin{tabular}{|c|c|c|c|c|c|c|c|c|c|c|c|c|}
\hline \multirow[b]{2}{*}{ Unit of study } & \multicolumn{2}{|c|}{ Mean score } & \multicolumn{2}{|c|}{$\%$ Fail } & \multicolumn{2}{|c|}{$\%$ Pass } & \multicolumn{2}{|c|}{$\%$ Credit } & \multicolumn{2}{|c|}{$\begin{array}{l}\% \\
\text { Distinction }\end{array}$} & \multicolumn{2}{|c|}{$\begin{array}{l}\text { \% High } \\
\text { Distinction }\end{array}$} \\
\hline & Total & $\begin{array}{l}\text { EAP } \\
(n)\end{array}$ & Total & EAP & Total & EAP & Total & EAP & Total & EAP & Total & EAP \\
\hline $\begin{array}{l}\text { Accounting Business \& } \\
\text { Society* }\end{array}$ & 64.69 & $\begin{array}{l}68.93 \\
(15)\end{array}$ & 13 & 13 & 27 & 27 & 36 & 40 & 20 & 13 & 0 & 7 \\
\hline $\begin{array}{l}\text { Biomechanics of Human } \\
\text { Movement }\end{array}$ & 60.69 & $\begin{array}{l}63.50 \\
(14)\end{array}$ & 16 & 0 & 41 & 57 & 21 & 36 & 15 & 7 & 0 & 0 \\
\hline Mathematical Modeling & 57.60 & $\begin{array}{l}57.36 \\
(14)\end{array}$ & 20 & 21 & 41 & 50 & 24 & 21 & 13 & 7 & 0 & 0 \\
\hline Psychology $1001^{*}$ & 58.15 & $\begin{array}{l}67.06 \\
(18)\end{array}$ & 22 & 0 & 36 & 44 & 23 & 28 & 15 & 17 & 4 & 11 \\
\hline Psychology 1002 & 57.37 & $\begin{array}{l}62.43 \\
(15)\end{array}$ & 21 & 26 & 38 & 33 & 23 & 13 & 15 & 20 & 3 & 7 \\
\hline Business Environment * & 61.17 & $\begin{array}{l}66.81 \\
(16) \\
\end{array}$ & 9 & 0 & 40 & 25 & 39 & 75 & 12 & 0 & 0 & 0 \\
\hline
\end{tabular}

*t-test $\mathrm{p}<.05$

\subsection{Comparison within the EAP cohort}

An outline of overall proportions in grades for all EAP student enrollments in 63 units is provided in Table 2. This table compares performance within the EAP group according to: gender; sport; faculty and by whether or not the EAP students were in residential colleges. Overall, over $25 \%$ of all EAP athletes scored a Distinction and above. Credit and above included more than $60 \%$ of the total cohort, while less than $5 \%$ of the students received a Fail. The overall EAP failure rate was $4.50 \%$, with $5.84 \%$ among males and $2.32 \%$ among females. This compared very favorably with the failure rate for all students within these 63 units examined which was $16 \%$.

Within the EAP group it is also clear that: 1) female perform better than males, with higher proportions in credit, distinction and high distinction grades; 2) among the different sports soccer and Australian football had weaker performance and Athletics and Hockey students showed the highest abilities; 3) EAP failure rates were highest in the Engineering faculty and strongest performance in seen in the Business and Education and Social Work faculties; and finally 4) although EAP students in residential colleges produced higher pass rates, they also had slightly higher failure rates and lower distinction rates that non-college EAP students.

\subsection{Interview themes}

As noted in the methodology, the interviews were conducted to yield further information pertaining to attainment and notable trends. While the questions focused on a range of issues, three clear themes emerged. These are presented along with data supporting them in Table 3.

First, EAP athletes believed that there is a perception amongst the general University student population and academic staff, that they are perceived and stereotyped as 'dumb jocks'. Second, EAP students support the view that their skills developed from the sporting arena, can be transferred and used within their academic domain and explain reasons for their perceived strong academic performances. Finally, students reported that the EAP at the University 
has not only assisted their sporting pursuits with cutting edge technology and support; but the policies and practices in place from an educational perspective had also enhanced their academic results and achievements.

Table 2. Summary of EAP athlete results for the 2012 Academic Year: Overall, Gender, Seven Largest Sports, Six Largest Faculties, Residential Colleges.

\begin{tabular}{|c|c|c|c|c|c|c|c|}
\hline $\begin{array}{l}\text { Group (total UOS } \\
\text { enrollments) }\end{array}$ & Fail & Pass & $\begin{array}{l}\text { R-satisfied } \\
\text { requirements }\end{array}$ & Credit & Distinction & $\begin{array}{l}\text { High } \\
\text { Distinction }\end{array}$ & Incomplete \\
\hline $\begin{array}{l}\text { EAP total } \\
(1932)\end{array}$ & $\begin{array}{l}87 \\
4.50 \% \\
\end{array}$ & $\begin{array}{l}531 \\
27.48 \%\end{array}$ & $\begin{array}{l}120 \\
6.21 \% \\
\end{array}$ & $\begin{array}{l}678 \\
35.09 \%\end{array}$ & $\begin{array}{l}405 \\
20.96 \%\end{array}$ & $\begin{array}{l}95 \\
4.92 \% \\
\end{array}$ & $\begin{array}{l}16 \\
0.83 \% \\
\end{array}$ \\
\hline Male (1198) & $\begin{array}{l}70 \\
5.84 \% \\
\end{array}$ & $\begin{array}{l}351 \\
29.30 \% \\
\end{array}$ & $\begin{array}{l}79 \\
6.59 \% \\
\end{array}$ & $\begin{array}{l}411 \\
34.31 \% \\
\end{array}$ & $\begin{array}{l}229 \\
19.12 \%\end{array}$ & $\begin{array}{l}45 \\
3.76 \% \\
\end{array}$ & $\begin{array}{l}13 \\
1.09 \% \\
\end{array}$ \\
\hline Female (734) & $\begin{array}{l}17 \\
2.32 \% \\
\end{array}$ & $\begin{array}{l}180 \\
24.52 \% \\
\end{array}$ & $\begin{array}{l}41 \\
5.59 \% \\
\end{array}$ & $\begin{array}{l}267 \\
36.38 \% \\
\end{array}$ & $\begin{array}{l}176 \\
23.98 \% \\
\end{array}$ & $\begin{array}{l}50 \\
6.81 \% \\
\end{array}$ & $\begin{array}{l}3 \\
0.41 \% \\
\end{array}$ \\
\hline $\begin{array}{l}\text { Rugby Union } \\
\text { (309) }\end{array}$ & $\begin{array}{l}26 \\
8.41 \% \\
\end{array}$ & $\begin{array}{l}104 \\
33.66 \% \\
\end{array}$ & $\begin{array}{l}5 \\
1.62 \% \\
\end{array}$ & $\begin{array}{l}113 \\
36.57 \% \\
\end{array}$ & $\begin{array}{l}51 \\
16.50 \% \\
\end{array}$ & $\begin{array}{l}5 \\
1.62 \% \\
\end{array}$ & $\begin{array}{l}5 \\
1.62 \% \\
\end{array}$ \\
\hline Athletics (301) & $\begin{array}{l}11 \\
3.65 \% \\
\end{array}$ & $\begin{array}{l}73 \\
24.25 \%\end{array}$ & $\begin{array}{l}16 \\
5.32 \% \\
\end{array}$ & $\begin{array}{l}102 \\
33.89 \%\end{array}$ & $\begin{array}{l}80 \\
26.58 \%\end{array}$ & $\begin{array}{l}18 \\
5.98 \% \\
\end{array}$ & $\begin{array}{l}1 \\
0.33 \% \\
\end{array}$ \\
\hline $\begin{array}{l}\text { Rowing } \\
\text { (143) }\end{array}$ & $\begin{array}{l}6 \\
4.20 \% \\
\end{array}$ & $\begin{array}{l}58 \\
40.56 \% \\
\end{array}$ & $\begin{array}{l}0 \\
0 \% \\
\end{array}$ & $\begin{array}{l}50 \\
34.97 \% \\
\end{array}$ & $\begin{array}{l}21 \\
14.69 \% \\
\end{array}$ & $\begin{array}{l}6 \\
4.20 \% \\
\end{array}$ & $\begin{array}{l}2 \\
1.40 \% \\
\end{array}$ \\
\hline $\begin{array}{l}\text { Soccer } \\
(\mathbf{1 8 0}) \\
\end{array}$ & $\begin{array}{l}8 \\
4.44 \% \\
\end{array}$ & $\begin{array}{l}56 \\
31.11 \% \\
\end{array}$ & $\begin{array}{l}19 \\
10.56 \% \\
\end{array}$ & $\begin{array}{l}52 \\
28.89 \% \\
\end{array}$ & $\begin{array}{l}37 \\
20.56 \% \\
\end{array}$ & $\begin{array}{l}8 \\
4.44 \% \\
\end{array}$ & $\begin{array}{l}0 \\
0 \% \\
\end{array}$ \\
\hline Hockey (133) & $\begin{array}{l}3 \\
2.26 \% \\
\end{array}$ & $\begin{array}{l}35 \\
26.32 \%\end{array}$ & $\begin{array}{l}11 \\
8.27 \% \\
\end{array}$ & $\begin{array}{l}43 \\
32.33 \%\end{array}$ & $\begin{array}{l}23 \\
17.29 \% \\
\end{array}$ & $\begin{array}{l}18 \\
13.53 \%\end{array}$ & $\begin{array}{l}0 \\
0 \% \\
\end{array}$ \\
\hline Cricket (97) & $\begin{array}{l}4 \\
4.12 \% \\
\end{array}$ & $\begin{array}{l}25 \\
25.77 \% \\
\end{array}$ & $\begin{array}{l}15 \\
15.46 \% \\
\end{array}$ & $\begin{array}{l}30 \\
30.93 \% \\
\end{array}$ & $\begin{array}{l}18 \\
18.56 \% \\
\end{array}$ & $\begin{array}{l}5 \\
5.15 \% \\
\end{array}$ & $\begin{array}{l}0 \\
0 \% \\
\end{array}$ \\
\hline AFL (91) & $\begin{array}{l}5 \\
5.49 \% \\
\end{array}$ & $\begin{array}{l}30 \\
32.97 \% \\
\end{array}$ & $\begin{array}{l}13 \\
14.29 \% \\
\end{array}$ & $\begin{array}{l}33 \\
36.26 \% \\
\end{array}$ & $\begin{array}{l}7 \\
7.69 \% \\
\end{array}$ & $\begin{array}{l}1 \\
1.10 \% \\
\end{array}$ & $\begin{array}{l}2 \\
2.20 \% \\
\end{array}$ \\
\hline Business (351) & $\begin{array}{l}9 \\
2.56 \% \\
\end{array}$ & $\begin{array}{l}73 \\
20.80 \% \\
\end{array}$ & $\begin{array}{l}9 \\
2.56 \% \\
\end{array}$ & $\begin{array}{l}146 \\
41.60 \%\end{array}$ & $\begin{array}{l}94 \\
26.78 \%\end{array}$ & $\begin{array}{l}16 \\
4.56 \% \\
\end{array}$ & $\begin{array}{l}4 \\
1.14 \% \\
\end{array}$ \\
\hline $\begin{array}{l}\text { Health Science } \\
\text { (377) }\end{array}$ & $\begin{array}{l}17 \\
4.51 \% \\
\end{array}$ & $\begin{array}{l}105 \\
27.85 \% \\
\end{array}$ & $\begin{array}{l}7 \\
1.86 \% \\
\end{array}$ & $\begin{array}{l}153 \\
40.58 \% \\
\end{array}$ & $\begin{array}{l}83 \\
22.02 \% \\
\end{array}$ & $\begin{array}{l}12 \\
3.18 \% \\
\end{array}$ & 0 \\
\hline Science (296) & $\begin{array}{l}17 \\
5.74 \% \\
\end{array}$ & $\begin{array}{l}124 \\
41.89 \%\end{array}$ & $\begin{array}{l}6 \\
2.03 \% \\
\end{array}$ & $\begin{array}{l}86 \\
29.05 \% \\
\end{array}$ & $\begin{array}{l}50 \\
16.89 \% \\
\end{array}$ & $\begin{array}{l}11 \\
3.72 \% \\
\end{array}$ & $\begin{array}{l}2 \\
0.68 \%\end{array}$ \\
\hline Arts (161) & $\begin{array}{l}5 \\
3.11 \% \\
\end{array}$ & $\begin{array}{l}43 \\
26.71 \%\end{array}$ & $\begin{array}{l}5 \\
3.11 \% \\
\end{array}$ & $\begin{array}{l}65 \\
40.37 \%\end{array}$ & $\begin{array}{l}32 \\
19.88 \%\end{array}$ & $\begin{array}{l}7 \\
4.35 \% \\
\end{array}$ & $\begin{array}{l}4 \\
2.48 \% \\
\end{array}$ \\
\hline $\begin{array}{l}\text { Engineering and } \\
\text { IT (218) }\end{array}$ & $\begin{array}{l}21 \\
9.63 \%\end{array}$ & $\begin{array}{l}66 \\
30.28 \%\end{array}$ & $\begin{array}{l}5 \\
2.29 \%\end{array}$ & $\begin{array}{l}72 \\
33.03 \%\end{array}$ & $\begin{array}{l}38 \\
17.43 \%\end{array}$ & $\begin{array}{l}14 \\
6.42 \%\end{array}$ & $\begin{array}{l}2 \\
0.92 \%\end{array}$ \\
\hline $\begin{array}{l}\text { Education \& } \\
\text { Social Work (165) }\end{array}$ & $\begin{array}{l}4 \\
2.42 \% \\
\end{array}$ & $\begin{array}{l}22 \\
13.33 \% \\
\end{array}$ & $\begin{array}{l}21 \\
12.73 \% \\
\end{array}$ & $\begin{array}{l}53 \\
32.12 \% \\
\end{array}$ & $\begin{array}{l}44 \\
26.67 \% \\
\end{array}$ & $\begin{array}{l}21 \\
12.73 \% \\
\end{array}$ & $\begin{array}{l}0 \\
0 \% \\
\end{array}$ \\
\hline Colleges (378) & $\begin{array}{l}25 \\
6.61 \% \\
\end{array}$ & $\begin{array}{l}133 \\
35.19 \\
\end{array}$ & $\begin{array}{l}11 \\
2.91 \% \\
\end{array}$ & $\begin{array}{l}139 \\
36.77 \%\end{array}$ & $\begin{array}{l}52 \\
13.76 \%\end{array}$ & $\begin{array}{l}17 \\
4.50\end{array}$ & $\begin{array}{l}1 \\
0.26 \% \\
\end{array}$ \\
\hline $\begin{array}{l}\text { Non- college } \\
(1554)\end{array}$ & $\begin{array}{l}62 \\
4.00 \%\end{array}$ & $\begin{array}{l}397 \\
25.55 \%\end{array}$ & $\begin{array}{l}110 \\
7.08 \%\end{array}$ & $\begin{array}{l}539 \\
34.68 \%\end{array}$ & $\begin{array}{l}353 \\
22.72 \%\end{array}$ & $\begin{array}{l}78 \\
5.02 \%\end{array}$ & $\begin{array}{l}15 \\
0.97 \%\end{array}$ \\
\hline
\end{tabular}

a. The grades refer to the following scores: (Fail <50; Pass 50-64; Credit 65-74; Distinction 75-84; High Distinction 84-100).

b. The R column refers to units which are Pass / Fail. In the analysis of each of the variable, 'R' results will simply be put in the pass column.

c. Fail Grades refers to receiving a grade under 50, absent fail, discontinued with or without permission.

d. At the time of receiving the results a number of units were not finalized and have been entered in a column as incomplete. These results were not part of any analysis. 
Participants clearly enunciated that within the university culture, elite athletes are often stereotyped as 'dumb jocks'. Part of this perception is associated with the prominence of professional mainstream athletes who are consistently portrayed in the mass media, particularly in sports such as Rugby League, Rugby Union and AFL. This perception has been identified from both the general university cohort and also the academic staff. Respondent 1 noted: "Often there is a perception that if you come through a sports program, that it helps you get into uni in the first place". It would seem that the challenge is related in some part to the extra five points available for EAP student entry and "people think we get it easier than other student, because we play sport for the uni" (Respondent 5). Respondent 2 perhaps best summed up the feelings of the athletes: "there is definitely this dumb jock stereotype, of the uninterested, bored, athlete in class, who is there really only because they have to be, not because they want to be".

This stereotype is also more pertinent in particular sports, such as Rugby Union, where Respondent 3 and 8 highlighted respectively that "[t]here is definitely a dumb jock persona attached to being an elite athlete, especially for footballers" and that "footy players, generally tend to get stereotyped as the dumb jocks". Perhaps some of this typifying stems from the idea that elite athletes are given more study time, support, or opportunity. Most of the interviewees felt antagonism from the general university cohort, for example: "there is some hostility towards athletes getting out of work or rescheduling assignments for sporting commitments" (Respondent 10). Therefore, elite athletes' perception of the broader University cohort attitudes towards them revealed the conception of the 'dumb jock' is operative.

The next theme was related to their own perceptions. While the EAP athletes were not informed of any results of the study, most believed that they already were performing above the average university student population. Part of this was related to the skills learnt from their sporting and sporting experiences. Respondent 8 highlighted that the "underlying ethos in terms of playing competitive sport can translate to study", while Respondent 3 noted, "it is extremely beneficial. The skills you learn in sport and also studying hold you in great steps for the rest of your life. They are often skills that people in the work place really want to see".

Other athletes identified specific skills such as, time management, organization, and multi-tasking as direct skills that have been developed through sport and further transferred into the academic domains to enhance achievement. For example, Respondent 16 noted that, "Yes, it teaches you to multitask, it teaches you good communication skills, and to work with other people", while in the time management domain, Respondent 9 reported "I think it does, because you learn from an early age to manage your time really well, so I think it's been really effective". Organization was clearly another theme as Respondent 2 concluded: "Organization definitely, it's so important, especially when you've got so much training to fit in the time to do the same amount of studies as everybody else, and maybe fit it into a smaller amount of time". This was further supported by Respondent 3 who concluded: "sport has definitely helped my academic performance; the discipline, time management, efficiency in what you do and a balance to your life". The need for a balanced life was noted, and the philosophy of a healthy mind in a healthy body was paramount to success in both domains "Sport has allowed me to clear my head and go back to study with a clear mind" (Respondent, 15). Therefore, it was clear that all elite athletes believed that sport in some way had helped their academic goals and achievements. 
Table 3. Themes and data from interviews

\begin{tabular}{|c|c|}
\hline $\begin{array}{l}\text { Emerging } \\
\text { themes }\end{array}$ & Exemplar verbatim data \\
\hline $\begin{array}{l}\text { Dumb Jock } \\
\text { Stereotype }\end{array}$ & $\begin{array}{l}\text { - People think we get it easier than other students, because we play sport for the uni (5) } \\
\text { - Often there is a perception that if you come through a sports program, that its helps you get into uni in the first } \\
\text { place (1) } \\
\text { - There is definitely this dumb jock stereotype, of the uninterested, bored, athlete in class, who is there really } \\
\text { only because they have to be, not because they want to be (2) } \\
\text { - I think another stigma is the fact that you are an EAP athlete, some people think, you are just here for your } \\
\text { sporting ability (18) } \\
\text { - There is definitely a dumb jock persona attached to being an Elite athlete, especially for footballers (3) } \\
\text { - I think they think we don't take uni seriously (19) }\end{array}$ \\
\hline $\begin{array}{l}\text { Skills that } \\
\text { are } \\
\text { transferable } \\
\text { to academic } \\
\text { work }\end{array}$ & $\begin{array}{l}\text { - Yes, it teaches you to multitask, it teaches you good communication skills, and to work with other people (16) } \\
\text { - If you tend to be a high performer in one area, you're not necessarily going to be smart but you're going to be } \\
\text { learn what strategies to use to get results, I guess that applies to both fields (9) } \\
\text { - I think, mainly, application of the same way you motivate yourself to get better in sport, you can motivate } \\
\text { yourself to get better in study ( } 8 \text { ) } \\
\text { - Organization definitely, it's so important, especially when you've got so much training to fit in the time to do } \\
\text { the same amount of studies as everybody else, and maybe fit it into a smaller amount of time (2) } \\
\text { - Sport has definitely helped my academic performance, the discipline, time management, efficiency in what you } \\
\text { - It and a balance to your life (3) } \\
\text { your life. They are often skills that people in the work place really want to see (3) }\end{array}$ \\
\hline $\begin{array}{l}\text { Support } \\
\text { from EAP } \\
\text { enhances } \\
\text { academic } \\
\text { achievement }\end{array}$ & $\begin{array}{l}\text { - Tutoring offered through EAP has certainly helped me (4) } \\
\text { - They are doing quite a lot of good things. I know plenty of people who have got a lot out of the tutoring (6) } \\
\text { - One of the things that has definitely helped me is the tutoring that gets offered to the athletes here. Also, access } \\
\text { to seminars for essay writing and that sort of stuff (18) } \\
\text { - The EAP has been tremendous for me; it's given me structure, given me support, and more importantly access } \\
\text { to tutors and people who were able to educate me about the processes (3) } \\
\text { - I've actually consulted the sports psychologist through the EAP, which has really helped me gain focus to } \\
\text { apply myself (13) } \\
\text { - Being able to consult tutors, and things like that as well, which has been really helpful in getting my credit } \\
\text { average, to get into the masters course (13) }\end{array}$ \\
\hline
\end{tabular}

The final theme identified from the interviews, was that the EAP at the University has enhanced athletes' academic results and achievements. All interview participants identified the EAP as having contributed to individual academic success. Noted factors included: tutors; the clear expectations of what is required at a tertiary level; support services such as access to nutritionist, strength and conditioning, sports psychologists; and communication and negotiation with academic staff. For example Respondent 3:"The EAP has been tremendous for me, it's given me structure, given me support, and more importantly access to tutors and people who were able to educate me about the processes".

According to respondents the tutors were perhaps the most valuable of all provisions. For example "one of the things that has definitely helped me, is the tutoring that gets offered to the athletes here" (Respondent 18). Further, respondents 4 and 11 noted respectively that, "tutoring offered through EAP has certainly helped me" and "firstly the EAP has helped a lot with some of the tutoring I have received".

While tutoring was a major support avenue, other support that is offered and has been utilized by the athletes includes sports psychology, nutrition, and support and communication with academic staff. For example, respondent 15, "I've actually consulted the sports psychologist through the EAP, which has really helped me gain focus to apply myself”, whilst Respondent 19 reflects "EAP are really good at helping out with getting things like extensions, tutors and stuff like that, which is really helpful". Finally, the expectations placed on EAP athletes are well known and understood, for example "you have to meet standards .... Failing (subjects) can trigger an exit from the program" (Respondent 19) as there are expectations which govern the EAP. 


\section{Discussion}

Analysis of the EAP results suggests that elite athlete academically attained at an equivalent or superior level than the general university population. For example, comparison of mean scores in six units show that in half of the units, EAP athletes were statistically similar to the whole cohort and in half they performed statistically better. This is consistent with other studies looking at disaggregated groups of elite athletes (Jonker, et.al., 2009). There were also comparatively higher percentages of Credits, Distinctions and High Distinctions with a lower number of Passes and Failure rates among EAP athletes. While it is clear that EAP athletes have performed equivalent or superior on a range of indicators, it is arguably the analysis of Failure rates which reveals success of these athletes, and the program that supports them.

It might be surmised that this is due to the flexibility in the academic attendance policy that is part of the program and also the arrangements for reduced study load. Furthermore, consistent with other studies suggesting academic expectations are important (Hildebrand, 2005), interviews suggest that while lecturers and peers may still view these athletes as "dumb jocks", within the EAP program there are clearly high expectations of academic performance. Furthermore, in addition to the university wide "students at risk" policy and processes the EAP program has additional support for at risk students, which may have been influential in reducing the failure rate.

Within elite athlete research there appears to be emerging realization that these athletes are not a homogenous group. Our study shows that within an elite Australian university, with a formal academic support program for athletes, EAP students attain equal or above results in comparison to their peers. It is possible that the EAP students at this university are unique and that findings from other Australian universities would be different. The university has one of the largest, most established sports programs, that produce athletes of the highest quality, and the university is elite with high entry requirements. The students examined here may also be a unique sub-group in terms of the qualities of the program at the university. With elite athlete programs, it is not what you do but how you do it, and the quality of elite athlete programs is important. In this case, strategic and continual improvement of the program has, according to student interviews, addressed many of their concerns. These include: an appropriate attendance requirement policy, approved leave of absence, high expectations, social and community support events and some of these athletes undertook lower loads of study, even though in many programs and faculties part time study is not permitted.

The strength of this research is the comparison on specific units of study, as previous research has predominately focused on GPA and summary attainment (Comeaux \& Harrison, 2011). It is well-established that, in response to the shift from normative to standards based assessment in universities, the distribution of scores and grades within universities varies among faculties and courses, thus this study has taken a careful comparative approach, controlling for this factor. This is countered by the weaknesses of relatively small sample sizes for the unit of study analysis and also for analyses that examined students in faculties and sports. For insight into attainment in different elite sports and in different degree programs there is a need for larger sample, cross-institutional, studies.

\section{Conclusion}

This study has been timely, not only because there has been a lack of academic treatment given to the academic achievement of Australian elite athletes, but also because of the issues surrounding elite athletes receiving constant media attention operating to perpetuate 'the dumb jock syndrome'. Such media attention is evident in Australia as recently as September 2013, where issues surrounding controversial basketball scholarships in the exclusive NSW private school system generated headlines within media reports such as "A new kind of elite athlete" (Lehmann, 2013, pp.64-65), where one school "offering inducements to its basketball team" (ibid, 64) was subject to criticism.

Within the particular research undertaken at this University EAP scholarship holders have achieved equivalent or better results than the general student population; importantly dispelling the myth of the 'dumb jock syndrome'.

However, there is a need for similar research to be emulated in all Australian universities. Such studies should include data on a wide range of factors known to impact upon educational attainment. This would provide a more analytical perspective enabling deeper understanding of academic achievement among elite athletes and a more comprehensive account of the relationship between elite athlete sport and academic achievement in the Australian context. 


\section{References}

Berg, K. (2010). Justifying physical education based on neuroscience evidence. Journal of Physical Education, Recreation \& Dance, 81(3), 24-46. http://dx.doi.org/10.1080/07303084.2010.10598445

Braun, V., \& Clarke, V. (2006). Using thematic analysis in psychology. Qualitative research in psychology, 3(2), 77-101. http://dx.doi.org/10.1191/1478088706qp063oa

Creswell, J. W., \& Clark, V. L. P. (2007). Designing and conducting mixed methods research. Thousand Oaks, CA: Sage publications.

Comeaux, E. \& Harrison K.C. (2011). A conceptual model of academic success for student athletes. Educational Research, 40(5), 235-245.

Dexter, T. (1999). Relationship between sports knowledge, sports performance, and academic ability: Empirical evidence from GCSE physical education. Journal of Sport Sciences, 17(4), 283-295. http://dx.doi.org/10.1080/026404199366000

Dollman, J., Boshoff, K., \& Dodd, G. (2006). The relationship between curriculum time for physical education and literacy and numeracy standards in South Australian primary schools. European Physical Education Review, 12(2), 151-163. http://dx.doi.org/10.1177/1356336X06065171

Durand-Bush, N., \& Salmela, J.H. (2002). The development and maintenance of expert athletic performance: Perceptions of the World and Olympic Champions. Journal of Applied Sports Psychology, 14(1), 154-171. http://dx.doi.org/10.1080/10413200290103473

Dwyer, T., Blizzard, L., \& Dean, K., (1996). Physical activity and performance in children. Nutrition Reviews, 54(4), 27-31. http://dx.doi.org/10.1111/j.1753-4887.1996.tb03895.x

Dwyer, T., Coonan, W. E., Worsley, L. A., \& Leitch, D. R. (1979). An assessment of the effects of two physical activity programs on coronary heart disease risk factors in primary school children. Australian and New Zealand Journal of Public Health, 3(3), 196-202.

Espenshade, T. J., Chung, C. Y., \& Walling, J. L. (2004). Admission Preferences for Minority Students, Athletes, and Legacies at Elite Universities. Social Science Quarterly, 85(5), 1422-1446. http://dx.doi.org/10.1111/j.0038-4941.2004.00284.x

FitzSimons, P. (1994). Nick Farr-Jones: the Authorised Biography. Random House Australia.

Hickie, T.V. (1998). A Sense of Union: A History of the Sydney University Football Club. Playright Publishing.

Hildenbrand, K.J. (2005). An examination of college student athletes' academic achievement. Unpublished doctoral dissertation, Kansa State University, Manhattan, Kansas.

Hollis, L. P. (1998). Equal opportunity for student-athletes: Factors influencing student-athlete graduation rates in higher education. Unpublished doctoral dissertation, Boston University, Ann Arbor Michigan.

Horne, J., \& Sherington, G. (2012). Sydney: The Making of a Public University. Sydney: Sydney University Press.

Hutchinson, S. A., Wilson, M. E., \& Wilson, H. S. (1994). Benefits of participating in research interviews. Journal of Nursing Scholarship, 26(2), 161-166. http://dx.doi.org/10.1111/j.1547-5069.1994.tb00937.x

Intrator, S. M., \& Siegel, D. (2008). Project coach: Youth development and academic achievement through sport. Journal of Physical Education, Recreation \& Dance, 79(7), 17-24. http://dx.doi.org/10.1080/07303084.2008.10598210

Janssen, I., \& LeBlanc, A. G. (2010). Review Systematic review of the health benefits of physical activity and fitness in school-aged children and youth. International Journal of Behavioral Nutrition and Physical Activity, 7(40), 1-16.

Jonker, L., Elferink-Gemser, M.T., \& Visscher, C. (2009). Talented athletes and academic achievement: a comparison over 14 years. High Ability Studies, 20(1), 55-64. http://dx.doi.org/10.1080/13598130902863691

King, D. F. (1998). The use and characteristics of student athlete academic assistance programs in colleges and universities of the NAIA. Unpublished doctoral dissertation, Pepperdine University, Ann Arbor Michigan.

Knight Foundation. (2001). A call to action: reconnecting college sports and higher education. Retrieved August 2, 2013, from http://www.knightcommission.org/images/pdfs/2001_knight_report.pdf

Lambertson, A. (1998). A comparative study of the student-athlete academic support programs at the schools in the 
Mid-American Conference. (M.A. ed.). Microform Publications: Ball state University.

Lehmann, J. (28 ${ }^{\text {th }}$ September, 2013). A new kind of elite athlete. The Telegraph.

Lewis, J. E. (1997). Student-athlete perceptions regarding the academic support services at the University of North Carolina - Chapel Hill. Unpublished doctoral dissertation, University of North Carolina, Chapel Hill, North Carolina.

Lilienthal, S. (1997). Newtown Tarts: A history of Sydney universities women's sports association, 1910-1995. Allen \& Unwin.

Martin, K. (2010). Brain boost: sport and physical activity enhance children's learning. Retrieved April 13, 2013, from http://www.dsr.wa.gov.au/assets/files/Research/Brain\%20boost_emailer.pdf

Miller, P. S., \& Kerr, G. (2002). The athletic, academic and social experiences of intercollegiate student-athletes. Journal of Sport Behavior, 25(4), 346-367.

Mixon Jr, F. G. (1995). Athletics versus academics? Rejoining the evidence from SAT scores. Education Economics, 3(3), 277-283. http://dx.doi.org/10.1080/09645299500000025

Pascarella, E. T., \& Smart, J. C. (1991). Impact of intercollegiate athletic participation for African American and Caucasian men: Some further evidence. Journal of College Student Development, 32(2), 123-130.

Rasmussen, J.M. (2009). An Investigation of Scholar-Baller and Non Scholar-Baller Division I Football Student-Athletes' Academic, Athletic, Intrinsic Motivation and Athletic Identity. Unpublished doctoral dissertation, the University of Central Florida, Orlando, Florida.

Richards, S., \& Aries, E. (1999). The Division III student athlete: Academic performance, campus involvement, and growth. Journal of College Student Development, 40(3), 211-218.

Ryan, F. J. (1989). Participation in intercollegiate athletics: Affective outcome. Journal of College Student Development, 30(2), 122-128.

Sack, A. (2001). Big-time athletics vs. academic values: It's a rout. Chronicle of Higher Education, 59(1), 2-21.

Schroeder, P.J. (2000). An assessment of student involvment among selected NCCA division III basketball players. Journal of College Student Development, 41(6), 616-626.

Sherington, G. \& Georgakis, S. (2008). Sydney University Sport 1852-2007: more than a club. Sydney: Sydney University Press.

Shulman, J. L., \& Bowen, W. G. (2001). The game of life. Princeton, New Jersey: Princeton University Press.

Simons, H. D., Bosworth, C., Fujita, S., \& Jensen, M. (2007). The athlete stigma in higher education. College Student Journal, 41(2), 251-273.

Stegman, M. \& Stephens, L. J. (2000). Athletics and academics: are they compatible? High School Magazine, 7(6), 36-39.

Stuart, D. L. (1985). Academic preparation and subsequent performance of intercollegiate football players. Journal of College Student Personnel, 26(2), 124-129.

Suggs, W. (2003a). Grades and money: NCAA considers new rules that would tie sports participation to academic performance. Chronicle of Higher Education, 49(32), A43.

Suggs, W. (2003b). Jock majors: Many colleges allow football players to take the easy way out. Chronicle of Higher Education, 49(19), A33.

Umbach, P.D., Palmer, M.M., Kuh, G.D. \& Hannah, S.J. (2006). Intercollegiate Athletes and effective educational practice: Winning Combination or Losing Effort? Research in Higher Education, 47(6), 709-733. http://dx.doi.org/10.1007/s11162-006-9012-9

Unruh, R. L. (2001). Athletic department practices that relate to the academic performance and persistence of student-athletes. Unpublished doctoral dissertation, University of Oregon, Eugene Oregon.

Wolniak, G.C, Pierson, C.T., \& Pascarella, E.T. (2001). Effects of intercollegiate athletics participation on male orientations towards learning. Journal of College Student Development, 42(2), 604-624. 